\title{
Investigation of Organic Polymerization in Treating Waste Water by Electrolysis
}

\author{
Guang-Zai Nong, Ya-Lei Jiang, Shuang-Fei Wang \\ Institute of Light Industry and Food Engineering, Guangxi University, Guangxi, 530004, P. R \\ E-mail:wangsf@gxu.edu.cn
}

\begin{abstract}
Treating wastewater by bio-reactors combined with electrolytic cells gets better efficiencies in practices. Beside removal of pollutants by electro-oxidation reactions, organic polymerization is considered as another mechanism contributing to remove pollutants in treating wastewater by electrolysis. Therefore, an investigation of organic polymerization in wastewater by electrolysis is carried out in this paper. The common organic substrates of methanol, ethanol and glycol in water can be polymerized by electrolysis. Polymer precipitation contributes to removing $36.9 \%$ and $86.38 \%$ of COD of pulping wastewater and black liquor, respectively. The results indicate that organic polymerization plays an important role in pollutants reduction in treating wastewater by electrolysis.
\end{abstract}

\section{Keywords-waste water; black liquor; polymer; polymerization; electrolysis}

\section{INTRODUCTION}

Water is the source of life, and is one of the most abundant resources in the world [1]. However, with the increasing human activities, a large amount of wastewater is generated and discharged into rivers and sea, causing water pollution [2] that has threatened the survival of human being $[3,4]$. Therefore, treating wastewater before discharge is required, and to find effective wastewater treatments has become one of important research points in the world $[5,6,7]$.

The wastewater containing harmful organic compositions are generally called organic wastewater which is discharged from industry and the domestic living waste $[8,9]$. Anaerobic and aerobic bioreactors $[10,11]$ are commonly used to treat wastewater by converting the containing organic compositions into biogas including $\mathrm{CO} 2$ and fuel of $\mathrm{H} 2$ and $\mathrm{CH} 4[12,13]$. To further remove the biological inefficient compositions in wastewater, bio-electrochemical treatment system is usually combined with the bio-reactors to enhance their treating ability and efficiency [14]. For example, Tartakovsky, et al [15] increased $15.0 \%-20.0 \%$ of methane production in an up-flow anaerobic sludge blanket (UASB) reactor by combined with electrodes inside the sludge bed. Zhang, et al [16] improved the anode performance of a microbial electrolysis cell (MEC) combined anaerobic reactor for high concentration industrial wastewater treatment via dosing $\mathrm{Fe}(\mathrm{OH}) 3$. Feng, et al [17] increased $11 \%$ of VSS removal rate by equipped microbial electrolysis cells in an anaerobic reactor at an applied voltage of $0.3 \mathrm{~V}$. Yetilmezsoy, et al [18] carried a experiment to investigate the performance of an UASB reactor combined with an electrolytic cell, getting about $90.0 \%$ of COD and $92.0 \%$ of residual color removal.

Based on the facts raised above, there is a scientific question needs to consider: why combination with electrolytic cells that consumed minority of electric energy significantly enhances the ability and efficiency of COD removal? The answers' in references generally are: the pollutants were decomposed by electro-oxidation via two path-ways, directly by electron transfer and indirectly by active radicals such as $\cdot \mathrm{OH}, \cdot \mathrm{H}$, and $\cdot \mathrm{O}$. Those electro-oxidation reactions convert the pollutants into $\mathrm{CO} 2$ and $\mathrm{H} 2 \mathrm{O}$ [19]. Besides electro-oxidation reactions, organic polymerization is considered as another mechanism for enhancing pollutants removal in treating wastewater by electrolysis. This consideration is based on the practices that many of polymers generated and then became precipitates in the electrolytic reactor in our previous research on artificial photosynthesis [20]. Therefore, an investigation of the organic polymerization in wastewater water by electrolysis is carried out to test the consideration in this paper.

\section{METHODS}

\section{A. The Pulping Wastewater and Black Liquor}

Both pulping wastewater and black liquor were obtained from the Guangxi Huajing Co., Ltd. The chemical oxygen demand (CODCr) of the wastewater is $1236.8 \mathrm{mg} / \mathrm{L}$. The black liquor is in a concentration of (wt \%) $12.2 \%$ and a chemical oxygen demand (CODCr) of $119,198.4 \mathrm{mg} / \mathrm{L}$. The black liquor was generated from gumwood combined with bamboo. After combustion, the mass of the inorganic residue accounts for $43.8 \%$ of the dry solids; thereby, the organic components in the dry black liquor are estimated to be $56.2 \%$.

\section{B. The Designs of the Electrolytic Reactor}

The electrolytic reactor used in this study was separated to a cathode chamber and an anode chamber which was sealed up with Cationic exchange membranes. The anode and cathode plates were both constructed using titanium metal electrode.

\section{Investigation of Common Organic Substrates Polymerized by Electrolysis}

The organic substrates of methanol, ethanol and glycol were selected as simulating objections. $1.0 \%$ (wt \%) of those solutions were fed into the anode chamber of the electrolytic reactor, which was operated under $4.0 \mathrm{~V}$ of working voltage and $0.25 \mathrm{~mA}$ of current for four hours to obtain the corresponding polymers. 


\section{Investigation of the Polymerization in Treating Wastewater}

The pulping wastewater was fed into the anode chamber the reactor, which was operated under $4.0 \mathrm{~V}$ of working voltage and 12.5-2.5 mA of current for 120 hours.

\section{E. Investigation of the Polymerization in Treating Pulping Black Liquor}

First, a $200.0 \mathrm{ml}$ of black liquor was diluted to $900 \mathrm{ml}$, and then was into the anode chamber the reactor, which was operated under $4.0 \mathrm{~V}$ of working voltage and average $100.0 \mathrm{~mA}$ of current for 48 hours. In the reactor, $\mathrm{NaOH}$ and $\mathrm{H} 2$ were generated in cathode chamber; varieties of organic acids, lignin and some other organic polymers were generated in anode chamber (Shows in supplementary materials). Secondly, the acidified mixture was filtered by membrane filter, yielding wet biomass solids and acidic filtrate. $1,000 \mathrm{ml}$ of black liquor was treated completely in 240 hours, generating products of
$\mathrm{NaOH}, \mathrm{H} 2$, biomass solids and consuming electrical energy.

\section{RESULTS}

\section{A. The Results of the Polymerization on Common Organic Molecules}

Shown in Fig. 1 are the HPGPC spectrums of the electrolytic solutions generated from methanol, ethanol and glycol.

As shown in Fig. 1, there are polymers in low weight of $225 \mathrm{~g} / \mathrm{mol}$ and huge weight of $7.0 \times 105 \mathrm{~g} / \mathrm{mol}$ generated from methanol. Additionally, there are polymers in low weight of $187 \mathrm{~g} / \mathrm{mol}$ and huge weight of $2.0 \times 106 \mathrm{~g} / \mathrm{mol}$ generated from ethanol, and there are polymers in low weight of $271 \mathrm{~g} / \mathrm{mol}$ and huge weight of $9.8 \times 105 \mathrm{~g} / \mathrm{mol}$ generated from glycol. These HPGPC results of the polymers generated from methanol, ethanol and glycol. These results identify that the substrates of methanol, ethanol and glycol can be polymerized by electrolysis.

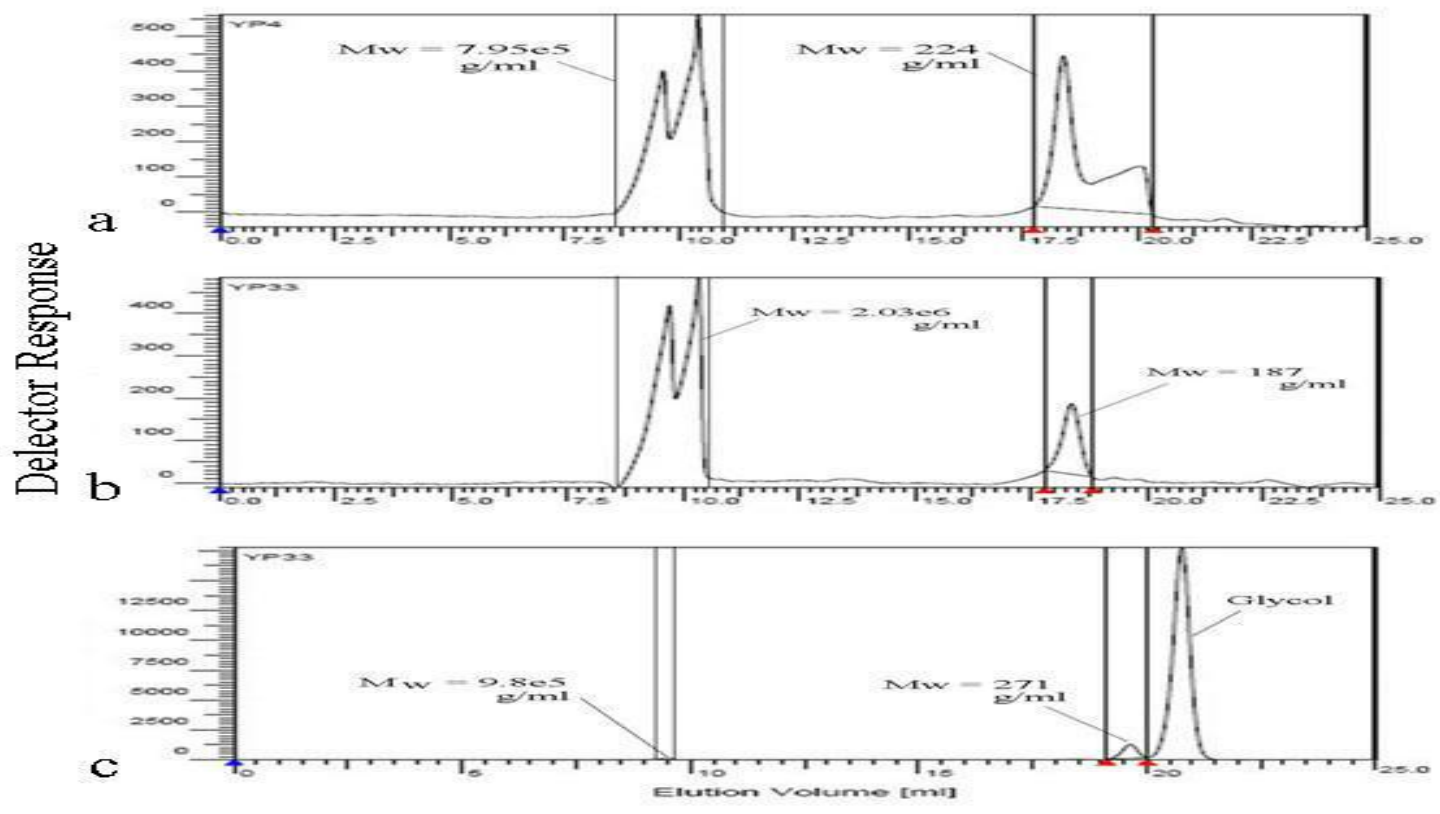

Figure 1. GPC spectrums of the electrolytic solutions generated from methanol (a), ethanol (b) and glycol (c)

\section{B. The Organic Polymerization in Treating Pulping Wastewater by Electrolysis}

After operation for 120 hours and filtration, A CODCr value of $1236.8 \mathrm{mg} / \mathrm{L}$ and colorimetric value of 50 times of the pulping wastewater from paper mill is reduced by electrolysis, obtained $217.3 \mathrm{mg}$ of a polymer precipitated and a residue filtrate with COD Cr value of $198.6 \mathrm{mg} / \mathrm{L}$.

Shown in Table 1 are the COD conversions in the treating process. In where, the COD masses of liquids were obtained by the multiplying of COD value and volume. The COD mass of the polymer precipitated was measured via digestion, while the COD mass of biomass converted to $\mathrm{CO} 2$ [19] was obtained by the calculation among the COD masses of the wastewater, the polymer precipitated and the residue filtrate. The ratios are the special COD mass comparing with the COD mass of wastewater.

Shown in Table 1, there is still some biomass remaining in the residue filtrate, contributing to $16.1 \%$ of the COD of wastewater. Thereby, total $83.9 \%$ of the COD mass is removed in 120 hours by electrolysis. In that $83.9 \%$ of COD mass removal, the polymer precipitated contributes to $36.9 \%$ of the COD of the wastewater. And thereby, the biomass converted to $\mathrm{CO} 2$ by oxidant reaction is calculated to be $47.0 \%$ of the COD of the wastewater. 
TABLE I. COD CONVERSION IN TREATING PULPING WASTEWATER BY ELECTROLYSIS

\begin{tabular}{ccccc}
\hline Contains & Numbers & COD inputted & COD outputted & Ratios \\
\hline wastewater & $1,000 \mathrm{ml}$ & $1,236.8 \mathrm{mg}$ & 0 & $100.0 \%$ \\
Polymer precipitated & $217.3 \mathrm{mg}$ & 0 & $456.3 \mathrm{mg}$ & $36.9 \%$ \\
Residue filtrate & $1,000.0 \mathrm{ml}$ & 0 & $198.6 \mathrm{mg}$ & $16.1 \%$ \\
Biomass converted to CO2 & uncertain & 0 & $581.9 \mathrm{mg}$ & $47.0 \%$ \\
Total & & $1,236.8 \mathrm{mg}$ & $1,236.8 \mathrm{mg}$ & \\
\hline
\end{tabular}

TABLE II. COD CONVERSION IN TREATING PULPING BLACK LIQUOR BY ELECTROLYSIS

\begin{tabular}{|c|c|c|c|c|}
\hline Contains & Numbers & COD inputted & COD outputted & Ratios \\
\hline Black liquor & $1,000 \mathrm{ml}$ & $119.20 \mathrm{~g}$ & 0 & $100.0 \%$ \\
\hline Polymer precipitated & $52.1 \mathrm{~g}$ & 0 & $102.97 \mathrm{~g}$ & $86.38 \%$ \\
\hline Residue filtrate & $1,000.0 \mathrm{ml}$ & 0 & $7.85 \mathrm{~g}$ & $6.59 \%$ \\
\hline Biomass converted to $\mathrm{CO} 2$ & uncertain & 0 & $8.38 \mathrm{~g}$ & $7.03 \%$ \\
\hline Total & & $119.20 \mathrm{~g}$ & $119.20 \mathrm{~g}$ & \\
\hline
\end{tabular}

\section{The Organic Polymerization In Treating Pulping Black Liquor By Electrolysis}

Shown in Table 2 are the COD conversions in treating black liquor by electrolysis. In where, the COD masses of liquids are obtained by the multiplying of $\mathrm{COD}$ value and volume. The COD masses of polymer precipitates are obtained by the minus between the COD masses of the generated suspension and the acidic filtrate. The COD mass of biomass converted to $\mathrm{CO} 2$ was obtained by the COD mass of the black liquor minus the COD mass of the generated suspension. The ratios are the results comparing with the COD mass of black liquor.

The COD value for the black liquor was 119198.4 $\mathrm{mg} / \mathrm{L}$. After electrolysing in for 96 hours, a suspension with COD Value of $110824.8 \mathrm{mg} / \mathrm{L}$ was obtained. And after removed the polymer precipitates by filtering, an acid filtrate polymerized to form a mixture with a COD value of $7847.6 \mathrm{mg} / \mathrm{L}$.

Based on Table 2, there is still some biomass remaining in the residue filtrate, contributing to $6.59 \%$ of the COD of the black liquor. The organic polymerization (including lignin and other polymers) contributes to $86.38 \%$ of the COD of black liquor, and can be removed by filtration, and the biomass converted to $\mathrm{CO} 2$ by oxidant reaction is calculated to be $7.03 \%$ of the COD of the black liquor.

\section{CONCLUSIONS}

Based on the experiments, conclusions can be draw as following: The common organic molecules of methanol, ethanol and glycol in water solutions can be polymerized by electrolysis. Polymer precipitated contributes to remove $36.9 \%$ and $86.38 \%$ of COD of pulping wastewater and black liquor, respectively. The results indicate that organic polymerization plays an important role in pollutants reduction in treating wastewater by electrolysis, and provide a new way to treat black liquor by recovery both biomass solids and sodium hydroxide.

\section{ACKNOWLEDGMENT}

The financial support for this project was from the Guangxi Natural Science Foundation (Grant \#: 2013jjFA20001).

$\mathrm{G} \mathrm{N}$ analyzed the spectra and prepared the manuscript. Y J and S W prepared and determined the polymers. All authors reviewed the manuscript. The authors declare no competing financial interests.

\section{REFERENCES}

[1] Mbah J, Weaver E, Srinivasan S, et al. "Low voltage H 2 O electrolysis for enhanced hydrogen production[J]."Energy, 2010, 35(12): 5008-5012.

[2] $\mathrm{Hu} \mathrm{Y}$, Cheng $\mathrm{H}$. "Water pollution during China's industrial transition[J]."Environmental Development, 2013, 8: 57-73.

[3] Lu Y, Song S, Wang R, et al. "Impacts of soil and water pollution on food safety and health risks in China[J]."Environment international, 2015, 77: 5-15.

[4] Levy G J, Fine P, Goldstein D, et al. "Long term irrigation with treated wastewater (TWW) and soil sodification[J]."biosystems engineering, 2014, 128: 4-10.

[5] Zhang C, Chen J, Wen Z. "Alternative policy assessment for water pollution control in China's pulp and paper industry[J].”Resources, Conservation and Recycling, 2012, 66: 15-26.

[6] Nair A T, Ahammed M M. "The reuse of water treatment sludge as a coagulant for post-treatment of UASB reactor treating urban wastewater[J]." Journal of Cleaner Production, 2015, 96: 272-281.

[7] Rondon H, El-Cheikh W, Boluarte I A R, et al. "Application of enhanced membrane bioreactor (eMBR) to treat dye waste water[J]."Bioresource technology, 2015, 183: 78-85.

[8] Nong G, Huang L, Mo H, et al. "Investigate the variability of gas compositions and thermal efficiency of bagasse black liquor gasification[J]." Energy, 2013, 49: 178-181.

[9] Han Q, Yan H, Zhang F, et al. "Trihalomethanes (THMs) precursor fractions removal by coagulation and adsorption for bio-treated 
municipal wastewater: Molecular weight, hydrophobicity/hydrophily and fluorescence[J]."Journal of hazardous materials, 2015, 297: 119-126.

[10] Ng K K, Shi X, Ng H Y. "Evaluation of system performance and microbial communities of a bioaugmented anaerobic membrane bioreactor treating pharmaceutical wastewater[J]." Water research, 2015, 81: 311-324.

[11] Wei D, Shi L, Yan T, et al. "Aerobic granules formation and simultaneous nitrogen and phosphorus removal treating high strength ammonia wastewater in sequencing batch reactor[J]." Bioresource technology, 2014, 171: 211-216.

[12] Narra M, Balasubramanian V. "Utilization of solid and liquid waste generated during ethanol fermentation process for production of gaseous fuel through anaerobic digestion-A zero waste approach[J]." Bioresource technology, 2015, 180: 376-380.

[13] Vijayaraghavan K, Ahmad D, Ibrahim M K B, et al. "Isolation of hydrogen generating microflora from cow dung for seeding anaerobic digester[J].” International journal of hydrogen energy, 2006, 31(6): 708-720.

[14] Ran Z, Gefu Z, Kumar J A, et al. "Hydrogen and methane production in a bio-electrochemical system assisted anaerobic baffled reactor[J]." International Journal of Hydrogen Energy, 2014, 39(25): 13498-13504.
[15] Tartakovsky B, Mehta P, Bourque J S, et al. "Electrolysis-enhanced anaerobic digestion of wastewater[J]." Bioresource technology, 2011, 102(10): 5685-5691.

[16] Zhang J, Zhang Y, Quan X, et al. "Enhanced anaerobic digestion of organic contaminants containing diverse microbial population by combined microbial electrolysis cell (MEC) and anaerobic reactor under Fe (III) reducing conditions[J]." Bioresource technology, 2013, 136: 273-280.

[17] Feng Y, Zhang Y, Chen S, et al. "Enhanced production of methane from waste activated sludge by the combination of high-solid anaerobic digestion and microbial electrolysis cell with iron-graphite electrode[J]." Chemical Engineering Journal, 2015, 259: 787-794.

[18] Yetilmezsoy K, Ilhan F, Sapci-Zengin Z, et al. "Decolorization and COD reduction of UASB pretreated poultry manure wastewater by electrocoagulation process: A post-treatment study[J]." Journal of hazardous materials, 2009, 162(1): 120-132.

[19] Zhu R, Yang C, Zhou M, et al. "Industrial park wastewater deeply treated and reused by a novel electrochemical oxidation reactor[J]." Chemical Engineering Journal, 2015, 260: 427-433.

[20] Nong G, Chen S, Xu Y, et al. "Artificial photosynthesis of oxalate and oxalate-based polymer by a photovoltaic reactor[J]." Scientific reports, 2014, 4. 